graves over against English or Irish" maintained. The chief discoveries made in the last ten years have been those of no less than seventy horned cairnis covering segmented cists in Ulster which, allowing for local differences, can be equated with the tombs of the Clyde and Solway coasts. Beacharra ware occurs in both these series of tombs. Further, it would appear that in Megalithic tomb times, southwest Scotland, north-east Ireland and the Isle of Man formed one province, while central and western Ireland and Scotland north of the Great Glen constituted another. Lastly, Prof. Childe uses the new discoveries to suggest an explanation of the anomalous occurrence of long cairns, horned at both ends, which have been found in northern Scotland.

\section{Raffles Museum, Singapore}

THE Bulletin of the Raffles Museum was suspended in 1941 when the Japanese occupied Singapore. It has now been revived, and the first issue of the new series (No. 18, October 1947) is made up of papers prepared before the occupation and preserved in the Museum. It is devoted almost entirely to the natural history of Christmas Island in the Indian Ocean and based on collections and field notes made on the island by C. A. Gibson-Hill between September 1938 and November 1940. Much of the bulletin describes the birds of the island; but notes are also included on the nature of the coast, climatic conditions from July 1939 to June 1940, echinoderms, Brachyura, terrestrial crabs, Arachnida, Isoptera, heterocerous and rhopalocerous Lepidoptera, terrestrial reptiles and mammals. The Bulletin also contains an obituary notice of the late director, F. N. Chasen, who was killed by enemy action in 1941.

\section{Textile Institute: Annual Conference}

THE subject of the annual conference of the Textile Institute, to be held at Buxton during June 2-5, will be "The Organisation of the Textile Industry". Among the authors of papers are Sir William Palmer (chairman, British Rayon Federation), Dr. F. C. Toy and Dr. D. W. Hill (British Cotton Industry Research Association) and Prof. A. N. Shimmin and Prof. A. J. Brown (University of Leeds). The Institute will also discuss its own role in the organisation of the industry at the opening session on June 2, when chairmen of its various committees will describe the work of their sections and their plans for the future, dealing in particular with education, standardization, publication, co-ordination, liaison and the status of the textile technologist. Foreign visitors to the conference include B. Hellmann and Dr. Zoltan Szaloki, who are to present a paper on "Textile Planning and Modernization in Czechoslovakia". Mr. Harold Wilson, President of the Board of Trade, has agreed to address the conference on June 2.

\section{Science Service Officers}

DR. KARL LARK-Horovitz, chairman of the Department of Physics, Purdue University, Lafayette, Indiana, and Charles E. Scripps of Cleveland, Ohio, have been elected trustees of Science Service, of Washington. Mr. Scripps represents the E. W. Scripps Estate, of which he is a trustee, while Dr. LarkHorovitz represents the American Association for the Advancement of Science, of which he is general secretary. The following officers have been re-elected : President, Dr. Harlow Shapley, director of Harvard
College Observatory; Vice-President and Chairman of the Executive Committee, Dr. Alexander Wetmore, secretary of the Smithsonian Institution; Treasurer, o. W. Riegel, director of the Lee School of Journalism, Washington, and Lee University, Lexington, Virginia; Secretary, Mr. Watson Davis, director of Science Service, Washington, D.C. Additional members of the Executive Committee are Mr. Frank R. Ford, editor of the Evansville Press, Evansville, Indiana; and Dr. E. G. Conklin, Princeton University, Princeton, New Jersey.

\section{British Medical Association: Annual Scientific Meeting}

THE first annual scientific meeting of the British Medical Association since the War will be held at Cambridge during June 25-July 2, under the presidency of Sir Lionel Whitby, regius professor of physic in the University. Among the topics of particular scientific interest announced for discussion are : recent advances in knowledge of the $R h$ factor in blood; plasma and blood derivatives in the treatment. of burns; human relations in industry; prophylaxis of virus infections; radioactive isotope therapy; aviation medicine; nutrition; antihistamine substances.

\section{International Summer School in Social Biology}

THE British Social Hygiene Council is organising a Summer School on "The International and Cultural Relations of Social Biology", at the University, Lausanne, Switzerland, during August 18-September 1. During the first week of the School, there will be two morning and one evening lecture sessions each day, except Sunday, while the second week will be free for visits, excursions, and personal recreation. The course is intended for students of biology, teachers, social workers, men and women in administrative positions, and all who are interested in problems of human welfare and culture. The estimated cost, including travel, hotel accommodation and tuition, will be about £35. Further information can be obtained from the Secretary, British Social Hygiene Council (Dept. S.J.1), Tavistock House North, Tavistock Square, London, W.C.1.

\section{Summer School in Health Education}

THE Central Council for Health Education is holding its annual Summer School in Health Education at 'High Leigh', Hoddesdon, Hertfordshire, during August 11-25. In addition to the basic lectures in physiology (by Prof. Samson Wright), psychology (by Prof. James Drever), the biology of infection (by Dr. Robert Cruickshank), and social factors affecting health (by Prof. J. M. Mackintosh), Dr. H. A. Wilson, the Bishop of Chelmsford, will speak on "The Spiritual Needs of Man", and Sir Alexander Fleming on "Penicillin". An interesting new development is that of a course of nature study, with rambles and evening discussions, illustrated by films, strips and bird-song records. The School will appeal especially to educational and medical administrators, doctors, teachers, youth leaders, public health nurses, industrial nurses, industrial welfare workers, training organisers and students. Further information can be obtained from the Medical Adviser and Secretary, the Central Council for Health Education, Tavistock House, Tavistock Square, London, W.C.l. The inclusive cost of the course per person will be $£ 1616 s$. 